\title{
Erratum to: Development and performance assessment of a qualitative SYBR® green real-time PCR assay for the detection of Aspergillus versicolor in indoor air
}

\author{
X. Libert $^{1,5}$ - C. Chasseur ${ }^{2}$ - S. Bladt ${ }^{3}$ - A. Packeu ${ }^{4}$ - F. Bureau ${ }^{5}$ - N. H. Roosens ${ }^{1}$. \\ S. C. J. De Keersmaecker ${ }^{1}$
}

Published online: 21 August 2015

(C) Springer-Verlag Berlin Heidelberg 2015

\section{Erratum to: Appl Microbiol Biotechnol}

DOI 10.1007/s00253-015-6785-9

The original version of this article inadvertently contains mistake. Table 5 was incorrectly presented. The correct Table is given below:

The online version of the original article can be found at http://dx.doi.org/ 10.1007/s00253-015-6785-9.

$\triangle$ S. C. J. De Keersmaecker

sigrid.dekeersmaecker@wiv-isp.be

1 Platform Biotechnology and Molecular Biology, Scientific Institute of Public Health (WIV-ISP), J. Wytsmanstraat 14, 1050 Brussels, Belgium

2 Health and Environment, Scientific Institute of Public Health (WIV-ISP), J. Wytsmanstraat 14, 1050 Brussels, Belgium

3 Cellule Régionale d'Intervention en Pollution Intérieure (CRIPI), Brussels Environment (IBGE), Avenue du Port 86C/3000, 1000 Bruxelles, Belgium

4 Mycology and Aerobiology, Scientific Institute of Public Health (WIV-ISP), J. Wytsmanstraat 14, 1050 Brussels, Belgium

5 Cellular and Molecular Immunology, Groupe Interdisciplinaire de Génoprotéomique Appliquée (GIGA), Université de Liège (ULg), Avenue de l'Hôpital, 1 (B34), 4000 Sart-Tilman, Belgium 
Table 5 Environmental sampling, comparison of classical analysis methods with the SYBR ${ }^{\circledR}$ green qPCR Aversi_ITS assay

\begin{tabular}{|c|c|c|c|c|c|c|c|}
\hline \multirow[b]{3}{*}{ Sampling place } & \multirow[b]{3}{*}{ Species } & \multicolumn{3}{|l|}{ Classical method } & \multicolumn{3}{|c|}{ Molecular method } \\
\hline & & \multicolumn{2}{|c|}{ RCS plus sampler and culturing } & \multirow{2}{*}{$\begin{array}{l}\text { Coriolis } \mu \text { sampler } \\
\text { and culturing } \\
\text { Number of colonies } \\
\text { per plate }\end{array}$} & \multicolumn{3}{|c|}{ Coriolis $\mu$ sampler and $\mathrm{qPCR}$} \\
\hline & & $\begin{array}{l}\text { Number of } \\
\text { colonies per plate }\end{array}$ & $\mathrm{CFU} / \mathrm{m}^{3} \mathrm{a}$ & & $\begin{array}{l}\text { Amount of } \\
\text { DNA/PCR } \\
\text { reaction }(n g)^{b}\end{array}$ & $\mathrm{C}_{\mathrm{q}}$ mean $\pm \mathrm{SD}^{\mathrm{c}}$ & $\begin{array}{l}\text { Theoretical copy } \\
\text { number of } \\
\text { gDNA for } 1 \mathrm{~m}^{3 \mathrm{~d}}\end{array}$ \\
\hline \multicolumn{8}{|l|}{ House 1} \\
\hline \multirow[t]{3}{*}{ Room } & A. versicolor & 3 & 38 & 9 & 19.8 & $32.15 \pm 0.49$ & 67 \\
\hline & P. chrysogenum & 7 & 88 & 17 & & & \\
\hline & Infertile mycelium & 0 & 0 & 1 & & & \\
\hline \multirow[t]{4}{*}{ Kitchen } & A. versicolor & 1 & 13 & 2 & 21.7 & $35.25 \pm 0.21$ & 7 \\
\hline & A. glaucus & 1 & 13 & 1 & & & \\
\hline & P. chrysogenum & 8 & 100 & 7 & & & \\
\hline & yeast (undetermined) & 1 & 13 & 1 & & & \\
\hline Living room & P. chrysogenum & 24 & 300 & 25 & 53.3 & N/A & / \\
\hline \multirow[t]{3}{*}{ Bathroom } & A. versicolor & 4 & 50 & 6 & 50 & $30.26 \pm 0.35$ & 93 \\
\hline & infertile mycelium & 4 & 50 & 4 & & & \\
\hline & P. chrysogenum & 15 & 188 & 17 & & & \\
\hline \multicolumn{8}{|l|}{ House 2} \\
\hline \multirow[t]{2}{*}{ Room 1} & infertile mycelium & 4 & 50 & 4 & 51.5 & N/A & l \\
\hline & P. chrysogenum & 17 & 213 & 15 & & & \\
\hline \multirow[t]{2}{*}{ Room 2} & infertile mycelium & 2 & 25 & 1 & 10.4 & N/A & l \\
\hline & P. chrysogenum & 3 & 38 & 4 & & & \\
\hline \multirow[t]{2}{*}{ Kitchen } & P. chrysogenum & 6 & 75 & 5 & 12.5 & N/A & / \\
\hline & infertile mycelium & 3 & 38 & 4 & & & \\
\hline \multirow[t]{2}{*}{ Living room } & A. versicolor & 1 & 13 & 2 & 49.5 & $35.85 \pm 0.07$ & 7 \\
\hline & P. chrysogenum & 18 & 225 & 20 & & & \\
\hline \multirow[t]{4}{*}{ Bathroom } & A. versicolor & 1 & 13 & 2 & 45 & $33.9 \pm 0.28$ & 33 \\
\hline & Cladosporium spp. & 1 & 13 & 1 & & & \\
\hline & P. chrysogenum & 15 & 188 & 13 & & & \\
\hline & yeast (undetermined) & 0 & 0 & 2 & & & \\
\hline
\end{tabular}

${ }^{\text {a }}$ The value for $\mathrm{CFU} / \mathrm{m}^{3}$ is an estimation of fungal contamination based on the number of colonies per plate. The Coriolis $\mu$ samples that were put into culture to serve as a qualitative control for the species identified with the RCS plus sampler and for A. versicolor detected in the Coriolis $\mu$ samples with the qPCR method. ${ }^{\mathrm{b}} 10 \mu \mathrm{l}$ of extracted DNA from $1.5 \mathrm{~m}^{3}$ sampled air (and eluted in $100 \mu \mathrm{l}$ of water) were use in a $25 \mu \mathrm{l}-\mathrm{PCR}$ reaction. ${ }^{\mathrm{c}} \mathrm{C}_{\mathrm{q}}$ values are $\mathrm{C}_{\mathrm{q}}$ means $(\leq 40) \pm$ standard deviation $(\mathrm{SD})$ obtained with the validated Aversi_ITS primers. N/A defined as no amplification, i.e. A. versicolor was considered as not detected in the sample. ${ }^{\mathrm{d}}$ Theoretical copy number of gDNA based on the Aspergillus versicolor IHEM 18884 strain defined as the strain of reference for the validation of the Aversi_ITS assay (Table 3b). 